\title{
PENGARUH PSIKOEDUKASI “GURU TAHU” TERHADAP PENINGKATAN PENGETAHUAN DASAR GURU TENTANG PESERTA DIDIK DI SEKOLAH INKLUSI
}

\section{THE EFFECT OF "TEACHER SHOULD KNOW" PSYCHOEDUCATIONAL TO IMPROVE TEACHERS' BASIC KNOWLEDGE ABOUT STUDENTS IN INCLUSIVE SCHOOLS}

\author{
Nur Widiasmara \\ H. Fuad Nashori \\ Uly Gusniarti \\ Fakultas Psikologi dan IImu Sosial Budaya Universitas Islam Indonesia Yogyakarta \\ Email: nurwidiasmara@gmail.com
}

\begin{abstract}
This study examines the influence of "What Every Teacher Should Know About Special Learners" psychoeducational in improving the basic knowledge of teachers in inclusive schools at SDN " $X$ ". The hypothesis was that there is an effect of "What Every Teacher Should Know About Special Learners" psychoeducational to teachers' basic knowledge about students in inclusive schools. The research design used the untreated control group design with dependent pretest and posttest sampels with adding follow up. A number of 18 teachers divided into the experimental group and control group in public elementary school being inclusive schools under the Education Department Government of Yogyakarta involved in this study. This study used teachers' basic knowledge about students with special needs tests (especially mental retardation and learning difficulties) with reliability coefficient of 0.799 . The psychoeducational module was developed based on training manual of Tileston (2005) adapted to the needs of teachers at $S D N$ " $X$ ". Data were analyzed using gain score method. The result shows that there is a difference in teachers' basic knowledge about students in inclusive schools between experimental group and control group (Mann-Whitney $U=7,500 ; Z=-2,925, p(1$-tailed) $=0,0015(p<0,05)$ ). This means that the "What Every Teacher Should Know About Special Learners" psychoeducational show influences in increasing the basic knowledge of teachers in inclusive schools at SDN " $X$ ". The result of this study confirmed the hypothesis.
\end{abstract}

Keywords: "Teacher Should Know" psychoeducation, teachers' basic knowledge in inclusive school.

\begin{abstract}
ABSTRAK
Penelitian ini menguji pengaruh Psikoedukasi "What Every Teacher Should Know About Special Learners" dalam meningkatan pengetahuan dasar guru SDN " $X$ " tentang peserta didik di sekolah inklusi. Hipotesis dalam penelitian ini adalah ada pengaruh psikoedukasi "What Every Teacher Should Know About Special Learners" terhadap pengetahuan dasar guru tentang peserta didik di sekolah inklusi. Rancangan penelitian menggunakan the untreated control group design with dependent pretest and posttest sampels dengan menambahkan tindak lanjut. Sebanyak 18 orang guru yang terbagi dalam kelompok eksperimen kelompok kontrol dari SD Negeri yang menjadi sekolah inklusi yang berada di bawah Dinas Pendidikan Pemerintah Kota Yogyakarta terlibat dalam penelitian ini. Penelitian ini menggunakan tes pengetahuan dasar guru
\end{abstract}


tentang peserta didik berkebutuhan khusus tunagrahita dan kesulitan belajar dengan koefisen reliabilitas sebesar 0,799. Modul Psikoedukasi dikembangkan berdasarkan manual pelatihan dari Tileston (2005) yang disesuaikan dengan kebutuhan guru di SDN " $\mathrm{X}$ ". Data dianalisis menggunakan metode selisih skor. Hasil menunjukkan bahwa ada perbedaan pengetahuan dasar guru tentang peserta didik di sekolah inklusi antara kelompok eksperimen dan kelompok kontrol (Mann-Whitney $U=7,500 ; Z=-2,925$, p (1-tailed) = $0,0015(p<0,05))$. Hal ini berarti bahwa psikoedukasi "What Every Teacher Should Know About Special Learners" menunjukkan pengaruh dalam peningkatan pengetahuan dasar guru SD N " $X$ " tentang peserta didik di sekolah inklusi. Hasil penelitian telah menguatkan hipotesis.

Kata Kunci: psikoedukasi "Teacher Should", pengetahuan dasar guru tentang peserta didik di sekolah inklusi.

SDN " $\mathrm{X}$ " yang berdiri sejak tahun 1980 merupakan salah satu sekolah penyelenggara pendidikan inklusi yang berada di Daerah Istimewa Yogyakarta (DIY). Prevalensi peserta didik berkebutuhan khusus yang ada di SDN " $X$ " terdiri atas tunagrahita sebanyak 15 peserta didik $(50 \%)$, kesulitan belajar sebanyak 14 peserta didik (47\%), dan tunaganda satu peserta didik (3\%). Berdasarkan hasil wawancara diketahui bahwa seluruh guru SDN " $X$ " masih menggunakan rencana pembelajaran yang telah dibuat sama bagi semua peserta didik dan belum memperhatikan kebutuhan peserta didik berkebutuhan khusus. Kondisi tersebut disebabkan guru belum mengetahui informasi secara spesifik mengenai karakteristik peserta didik berkebutuhan khusus dan bagaimana menanganinya.

Hasil analisis kondisi dan kebutuhan terhadap 9 guru SDN " $X$ " menunjukkan bahwa pengetahuan dasar tentang karakteristik peserta didik berkebutuhan khusus yang dimiliki guru SDN " $X$ " berada pada kategori rendah sebanyak $33,33 \%$, dan kategori sedang sebanyak $66,67 \%$. Secara umum, lebih dari $50 \%$ guru yang diambil datanya adalah perempuan, telah berusia lebih dari 46 tahun, berlatar belakang pendidikan Sarjana Pendidikan pada umumnya, sudah menjadi PNS dan telah mengajar lebih dari 19 tahun. Selain itu, $88,89 \%$ guru telah mengikuti pelatihan tentang pendidikan inklusi secara umum dan hanya $44,44 \%$ guru yang telah mengikuti pelatihan anak berkebutuhan khusus secara spesifik.

Hasil analisis kondisi dan kebutuhan terhadap guru juga memberikan gambaran bahwa guru SDN "X" mengalami kendala bagaimana mengenali dan menghadapi perbedaan karakteristik peserta didik berkebutuhan khusus (sebesar 44,44\%) serta bagaimana cara menyesuaikan pengajaran bagi peserta didik berkebutuhan khusus (sebesar 55,56\%). Guru SDN "X" mengharapkan adanya dukungan dana, sarana dan prasarana (sebesar $44,45 \%$ ), adanya pelatihan tentang cara menangani peserta didik berkebutuhan khusus di sekolah inklusi (sebesar $33,33 \%$ ), serta adanya guru 
pendamping khusus (sebesar 22,22\%).

Pemerintah Republik Indonesia pada dasarnya telah mengatur penyelenggaraan pendidikan inklusi dengan menetapkan Peraturan Menteri Pendidikan Nasional Republik Indonesia Nomor 70 Tahun 2009 tentang Pendidikan Inklusi bagi Peserta Didik yang Memiliki Kelainan dan Memiliki Potensi Kecerdasan dan/atau Bakat Istimewa. Mangunsong (2009) mengungkapkan bahwa sekolah inklusi merupakan sekolah yang memenuhi kebutuhan bagi semua individu yang ada di dalamnya, tanpa memandang tingkat kemampuan dan ketidakmampuan individu. Guru yang mengajar di sekolah inklusi perlu mengenali dan memahami karakteristik psikologis peserta didik maupun pendekatan pembelajaran yang tersendiri bagi kekhususan tersebut.

Pellegrino (2003) menambahkan bahwa untuk mengetahui kemampuan dan kebutuhan khusus peserta didik, guru harus memiliki pengetahuan dasar tentang peserta didik sebelum menyusun rencana pembelajaran yang akan dilaksanakan. Wiseman dkk (Rahman $d k k, 2010)$ mengungkapkan bahwa guru yang efektif menyadari perbedaan di antara peserta didik serta memahami pengaruh dari latar belakang, kemampuan, dan kebutuhan belajar yang berbeda dalam proses pembelajaran. Rahman dkk (2010) mengemukakan bahwa guru perlu memiliki pengetahuan dasar dan juga kesadaran bahwa peserta didik di kelas memiliki karakteristik yang berbeda dalam kemampuan dan kebutuhan yang berbeda.

Seluruh uraian tersebut menunjukkan bahwa pendidikan inklusi muncul sebagai salah satu upaya menempatkan peserta didik yang menyatu dalam sekolah yang sama, terlepas dari keberagaman kemampuan dan kebutuhan setiap peserta didik serta mensyaratkan guru untuk mampu melakukan penyesuaian proses pembelajaran. Guru perlu memiliki pengetahuan dasar tentang peserta didik berkebutuhan khusus dan mampu merancang pendekatan program pembelajaran yang sesuai dengan kemampuan dan kebutuhan peserta didik tersebut. Kenyataan di lapangan menunjukkan bahwa belum semua guru SDN " $X$ " mengetahui secara spesifik tentang karakteristik peserta didik berkebutuhan khusuus yang ada di sekolah. Oleh karena itu, perlu ada upaya pengembangan profesional bagi guru agar memiliki dan juga mampu menggunakan pengetahuan dasar tentang peserta didik berkebutuhan khusus dalam proses pembelajaran di kelas.

Menurut Departemen Pendidikan Nasional (2009), dalam rangka penyelenggaraan pendidikan inklusi, guru di sekolah reguler yang menjadi sekolah inklusi perlu dibekali berbagai pengetahuan tentang peserta didik 
berkebutuhan khusus dan bagaimana mengidentifikasinya. Supratiknya (2008) mengemukakan bahwa pendidikan psikologis (psikoedukasi) yang berupa model komprehensif yang mencakup konseling, training atau pelatihan, dan konsultasi dapat digunakan untuk membantu guru agar mampu mengembangkan diri secara optimal dalam menjalankan tugasnya. Sejalan dengan itu, Bennet dan Lopez (2010) mengungkapkan bahwa pengembangan profesional bagi guru harus diupayakan agar guru dapat memiliki pengetahuan dan keterampilan tentang karakteristik peserta didik dan bagaimana merespon dalam proses pembelajaran.

Tileston (2005) mengembangkan manual pelatihan dengan judul What Every Teacher Should Know About Diverse Learners. Manual pelatihan tersebut dapat digunakan untuk membantu guru dalam mengetahui tentang kemampaun dan kebutuhan serta bagaimana mengimplementasikan pengetahuan tersebut. Bennet dan Lopez (2010) mengungkapkan bahwa pengembangan profesional dalam bentuk pelatihan membantu guru mengenali serta menghargai perbedaan kemampaun dan kebutuhan peserta didik. Pelatihan yang dikembangkan Tileston bertujuan untuk mendukung guru dalam mengidentifikasi keberagaman kemampaun dan kebutuhan peserta didik. Guru akan belajar bagaimana mengetahui keberagaman kemampaun dan kebutuhan peserta didik serta mengimplementasikan dalam kelas.

Beberapa penelitian menunjukkan bahwa memberikan psikoedukasi dalam bentuk pelatihan yang sesuai dengan kebutuhan guru dapat meningkatkan pengetahuan dan kemampuan guru dalam melaksanakan tugas sebagai pendidik. Penelitian Gibss dan Coffey (2004) mengungkapkan bahwa pengembangan profesional guru melalui penerapan pelatihan secara signifikan dapat meningkatkan kemampuan mengajar guru dan pendekatan belajar yang digunakan peserta didik. Penelitian Noor (2010) mengungkapkan bahwa terdapat perbedaan yang signifikan antara tingkat pengajaran guru sebelum dan sesudah diberikan pelatihan. Penelitian Juwono dan Kumara (2011) merekomendasikan perlunya penelitian lanjutan untuk memusatkan perhatian pada pengetahuan guru untuk mengenali karakteristik peserta didik berkebutuhan khusus.

Seluruh uraian tersebut menunjukkan bahwa guru memiliki peran yang penting dalam pelaksanaan pendidikan inklusi. Guru SDN "X" perlu untuk memiliki pengetahuan dasar tentang karakteristik peserta didik berkebutuhan khusus secara mendalam sehingga dapat menyusun rencana pembelajaran yang sesuai. Pelatihan merupakan cara untuk dapat meningkatkan pengetahuan dan 
kemampuan guru dalam melaksanakan tugas. Oleh karena itu, guru SDN " $X$ " dapat diberikan pengetahuan mengenai peserta didik berkebutuhan khusus melalui psikoedukasi dalam bentuk pelatihan.

Peneliti tertantang untuk melakukan penelitian guna menyusun sebuah program psikoedukasi "What Every Teacher Should Know About Special Learners" yang dikembangkan berdasarkan manual pelatihan Tileston (2005) dan disesuaikan dengan kebutuhan guru di SDN " $X$ ". Program psikoedukasi tersebut dilakukan dalam bentuk pelatihan dan harapannya dapat meningkatkan pengetahuan dasar guru SDN " $X$ " tentang peserta didik berkebutuhan khusus (tunagrahita dan kesulitan belajar). Selain itu, guru SDN " $X$ " juga diharapkan dapat menggunakan pengetahuan tersebut dalam mendukung proses pembelajaran di sekolah.

$$
\text { Psikoedukasi "What Every }
$$
Teachers Should Know About Special Learners" selama 7 jam efektif dalam satu hari. Psikoedukasi tersebut dikembangkan berdasarkan manual pelatihan dari Tileston (2005). Psikoedukasi dalam penelitian ini lebih memfokuskan pada pengetahuan tentang peserta didik berkebutuhan khusus tunagrahita dan kesulitan belajar yang bersumber dari Departemen Pendidikan Nasional RI, Hallahan dan Kauffman (1994, 2006), Ormrod (2009), dan Mangunsong (2009). Peneliti melakukan perubahan pada jumlah kegiatan, materi, waktu, lembar kerja dan metode pembelajaran dari kegiatan pada manual pelatihan dari Tileston (2005) yang disesuaikan materi tentang peserta didik berkebutuhan khusus tunagrahita dan kesulitan belajar.

$$
\text { Psikoedukasi "What Every }
$$
Teachers Should Know About Special Learners" memasukkan teori tentang batasan/pengertian, prevalensi peserta didik berkebutuhan khusus serta karakteristik, klasifikasi, penyebab dan identifikasi peserta didik berkebutuhan khusus tunagrahita dan kesulitan belajar. Psikoedukasi tersebut meliputi kegiatan utama yang terdiri atas kegiatan menyiapkan proses pembelajaran, menguji perbendaharaan kosakata, menemukan informasi, praktek aplikasi, serta evaluasi dan refleksi. Psikoedukasi tersebut memiliki tujuan deklaratif yang didasarkan pada informasi faktual bahwa guru akan memiliki pengetahuan sebagai hasil dari pelatihan serta tujuan prosedural mengacu pada apa yang akan mampu dilakukan sebagai hasil dari pelatihan.

Kegiatan ke-1 merupakan serangkaian kegiatan untuk menyiapkan proses pembelajaran. Kegiatan ke-2 merupakan serangkaian kegiatan yang menguji perbendaharaan kosakata guru tentang perbedaan kelompok dan perbedaan individual termasuk peserta didik berkebutuhan khusus. Kegiatan ke3 merupakan serangkaian kegiatan yang 
mengajak guru untuk menemukan informasi tentang peserta didik. Kegiatan tersebut dibagi menjadi tiga bagian. Bagian I merupakan kegiatan membuat catatan pengetahuan. Bagian II merupakan kegitan penemuan informasi. Bagian III merupakan kegiatan menyimpulkan pengetahuan yang telah didapatkan melalui kegiatan penemuan informasi. Kegiatan ke-4 merupakan serangkaian kegiatan praktek aplikasi. Kegiatan terakhir adalah kegiatan ke-5 yang merupakan serangkaian kegiatan evaluasi dan refleksi.

Berdasarkan seluruh rangkaian kegiatan tersebut, psikoedukasi "What Every Teacher Should Know About Special Learners" diharapkan memberikan kesempatan bagi guru belajar secara aktif, mampu mendemonstrasikan hubungan antar kegiatan pembelajaran serta mampu menerapkan pengetahuan yang telah didapatkan dalam tugas mengajar peserta didik berkebutuhan khusus (Silberman, 1998; Ormord, 2009; Parkay \& Stanford, 2011). Psikoedukasi tersebut diharapkan dapat meningkatkan pengetahuan guru tentang tentang batasan/pengertian, prevalensi peserta didik berkebutuhan khusus serta karakteristik, klasifikasi, penyebab dan identifikasi peserta didik berkebutuhan khusus tunagrahita dan kesulitan belajar. Psikoedukasi juga diharapkan dapat meningkatkan pengetahuan dan kesadaran terhadap peserta didik berkebutuhan khusus di kelas.

Psikoedukasi "What Every Teacher Should Know About Special Learners" pada akhirnya akan menjadikan guru dapat memiliki dan meningkatkan pengetahuan, pemahaman serta kemampuan dasar yang harus dimiliki sebagai tenaga pendidik profesional di sekolah inklusi. Pelatihan tersebut menjadikan guru memiliki dan meningkat pengetahuan, pemahaman, serta kemampuannya secara spesifik mengenai peserta didik berkebutuhan khusus (Shulman, 1986). Peningkatan pengetahuan, pemahaman, dan kemampuan tersebut merupakan bagian dari peningkatan pengetahuan dasar guru tentang peserta didik berkebutuhan khusus tunagrahita dan kesulitan belajar.

Hipotesis yang diajukan dalam penelitian ini adalah ada pengaruh psikoedukasi "What Every Teacher Should Know About Special Learners" terhadap pengetahuan dasar guru tentang peserta didik di sekolah inklusi. Guru yang diberi perlakuan berupa psikoedukasi "What Every Teacher Should Know About Special Learners" (kelompok eksperimen) lebih tinggi pengetahuan dasar tentang peserta didik berkebutuhan khusus tunagrahita dan kesulitan belajar daripada guru yang tidak diberikan perlakuan (kelompok kontrol). 
(2009), Hallahan dan Kauffman (1994, 2006), Mangunsong (2009), Ormrod (2009), Santrock (2009), Shulman (1986, 1987), Suparno dkk (2007). Tes pengetahuan dasar tentang peserta didik di sekolah inklusi adalah tes prestasi belajar dengan bentuk multiple choice, yang berfungsi sebagai pengukuran sumatif guna menentukan nilai akhir dalam suatu program dan penentuan taraf penguasaan (Azwar, 2010). Taksonomi proses kognitif yang digunakan meliputi mengingat, memahami, dan menerapkan pengetahuan dasar tentang peserta didik berkebutuhan khusus.

Alat ukur berupa Tes Pengetahuan tentang Peserta Didik di Sekolah Inklusi yang telah dilakukan tryout preliminary, dianalisis dengan menggunakan program Item and Test Analysis (ITEMAN) Version 3.00. Hasil analisis berdasarkan kriteria pemilihan soal, menurut Hidayati (2009), menunjukkan bahwa tingkat kesukaran soal berada pada tingkat sedang, sukar, hingga mudah dan dapat diterima dengan koefisien prop. correct berkisar antara 0,125-0,844. Daya pembeda soal dapat diterima dengan koefisien biser berkisar antara 0,135 - 1,000. Proporsi jawaban menunjukkan bahwa jawaban dapat berfungsi dengan baik dan soal dapat digunakan dengan koefisien prop. endorsing berkisar antara 0,125 0,844 . Alat ukur memiliki koefisien 


\section{METODE PENELITIAN}

\section{Subjek Penelitian}

Pemilihan subjek penelitian menggunakan teknik nonprobability sampling. Menurut Myers dan Hansen (2002), teknik nonprobability sampling adalah teknik pemilihan subjek di mana subjek tidak dipilih secara acak. Subjek yang terlibat dalam penelitian adalah guru yang mengajar di dua SD Negeri yang menjadi sekolah inklusi di Kota Yogyakarta. Pengetahuan dasar guru tentang peserta didik di sekolah inklusi yang dimiliki guru tersebut berada pada kategori rendah hingga sedang. Jumlah guru yang menjadi subjek penelitian adalah 18 orang.

\section{Desain Penelitian}

Rancangan yang digunakan dalam penelitian adalah quasi experimental design. Menurut Myers dan Hansen (2002), quasi experimental design merupakan desain eksperimen yang digunakan ketika subyek tidak dapat dipilih secara acak untuk menerima perlakuan yang berbeda. Bentuk rancangan quasi experimental design yang digunakan adalah the untreated control group design with dependent pretest and posttest sampels seperti terlihat pada Gambar 1. Menurut Shadish, Cook, dan Campbell (2002), the untreated control group design with dependent pretest and posttest sampels merupakan salah satu quasi experimental design yang melibatkan kelompok eksperimen dan kelompok kontrol sebagai pembanding yang dipilih secara non random. Rancangan dalam the untreated control group design with dependent pretest and posttest sampels yang digunakan dalam penelitian ditambahkan dengan tindak lanjut.

\begin{tabular}{|ccccc|}
\hline NR (KE): & O1 & $\mathrm{X}$ & $\mathrm{O} 2$ & $\mathrm{O} 3$ \\
\hline $\mathrm{NR}(\mathrm{KK}):$ & $\mathrm{O} 1$ & & $\mathrm{O} 2$ & $\mathrm{O} 3$ \\
\hline
\end{tabular}

Gambar 1. Rancangan Penelitian

Keterangan

NR : Non random

KE : Kelompok eksperimen

KK : Kelompok kontrol

O1 : Pengukuran sebelum pemberian perlakuan

O2 : Pengukuran setelah pemberian perlakuan

O3 : Tindak lanjut

X : Perlakuan berupa pelatihan

\section{Pengukuran}

Metode pengumpulan data yang digunakan dalam penelitian ini adalah:

1. Tes Pengetahuan Dasar tentang Peserta Didik di Sekolah Inklusi.

Alat ukur yang digunakan dalam penelitian ini merupakan alat ukur yang disusun peneliti berdasarkan kajian literatur terhadap teori yang dikemukakan oleh Bloom (1956) dan Krathwohl (2002), Departemen Pendidikan Nasional RI 
yang membantu untuk mengetahui sejauhmana pengetahuan dan kemampuan peserta dalam menentukan terminologi yang berkaitan dengan keberagaman peserta didik melalui pengisian lembar kerja, diskusi, dan presentasi.

c. Kegiatan ke-3 dibagi dalam tiga bagian kegiatan. Bagian I merupakan kegiatan yang membantu peserta agar memiliki kemampuan membuat catatan apa yang diketahui tentang keberagaman peserta didik, kekhususan tunagrahita dan kesulitan belajar, serta strategi identifikasi peserta didik berkebutuhan khusus melalui pengisian lembar kerja, dan presentasi.Bagian II merupakan kegiatan yang membantu peserta agar memiliki pengetahuan tentang keberagaman peserta didik, kekhususan tunagrahita dan kesulitan belajar, startegi identifikasi peserta didik berkebutuhan khusus melalui presentasi dan diskusi. Permainan (games) merupakan permainan dengan menggunakan beberapa metode bermain interaktif yang dilaksanakan untuk memecah kejenuhan pada kegiatan bagian II. Bagian III merupakan kegiatan yang membantu peserta agar memiliki kemampuan membuat kesimpulan tentang keberagaman peserta didik, kekhususan tunagrahita dan kesulitan belajar, serta strategi identifikasi peserta didik berkebutuhan khusus melalui pengisian lembar kerja, diskusi, dan presentasi.

d. Kegiatan ke-4 merupakan kegiatan yang membantu peserta agar memiliki kemampuan menentukan kategori peserta didik berkebutuhan khusus tunagrahita dan kesulitan belajar melalui pengisian lembar kerja dan diskusi kasus, serta presentasi hasil diskusi kasus.

e. Kegiatan ke-5 merupakan kegiatan yang membantu peserta agar mampu mengevaluasi dan merefleksikan pengetahuan tentang peserta didik berkebutuhan khusus tunagrahita dan kesulitan belajar serta untuk mengevaluasi seluruh rangkaian pelatihan melalui pengisian lembar kerja, diskusi, dan presentasi.

f. Evaluasi pelatihan dilakukan untuk mengetahui apakah pelaksanaan pelatihan benar benar telah sesuai dengan tujuan peningkatan pengetahuan dasar tentang peserta didik berkebutuhan khusus. Evaluasi yang dilakukan dalam penelitian ini adalah (1) Evaluasi reaksi dilakukan untuk mengetahui 
apakah peserta menyukai program pelatihan, (2) Evaluasi pengetahuan dilakukan untuk mengetahui apa yang diketahui peserta sebelum diberikan perlakuan pelatihan dan yang telah dipelajari peserta setelah diberikan pelatihan, dan (3) Evaluasi perilaku dilakukan untuk mengetahui apakah sikap dan perilaku peserta berubah setelah mengikuti pelatihan.

3. Pengambilan data pascates dilakukan setelah dua minggu yang diberikan kepada kelompok eksperimen dan kontrol. Tindak lanjut dan survei psikoedukasi dengan kuisioner tipe isian diberikan pada subjek penelitian (kelompok eksperimen) setelah empat minggu pengambilan data pascates. Tindak lanjut juga diberikan pada kelompok kontrol.

4. Tahap terakhir adalah melakukan analisis atas keseluruhan data yang diperoleh. Psikoedukasi dikatakan efektif apabila tingkat pengetahuan dasar peserta tentang peserta didik di sekolah inklusi mengalami peningkatan.

\section{Teknik Analisis Data}

Pengujian hipotesis dilakukan dengan menggunakan statistik non parametrik (Field \& Hole, 2003). Hipotesis diuji melalui uji 2 Independent Samples T-Test dengan menggunakan statistik non paraemtrik The MannWhitney Test. The mann-whitney test merupakan statistik non parametrik yang digunakan untuk menguji ada tidaknya perbedaan skor dua kelompok yang dilibatkan dalam dua kondisi antara diberikan perlakuan dan yang tidak diberikan perlakuan. Seluruh perhitungan dilakukan dengan komputer menggunakan program SPSS 11.5 for Windows.

\section{HASIL PENELITIAN}

\section{Deskripsi Data}

Berdasarkan hasil perhitungan statistika, seperti terlihat pada Gambar 2, tampak bahwa rerata pengetahuan dasar guru tentang peserta didik berkebutuhan khusus (tunagrahita dan kesulitan belajar) antara prates, pascates, dan tindak lanjut pada kelompok eksperimen dan kelompok kontrol mengalami perubahan. Rerata pengetahuan dasar guru tentang peserta didik berkebutuhan khusus (tunagrahita dan kesulitan belajar) kelompok eksperimen lebih tinggi daripada kelompok kontrol. 


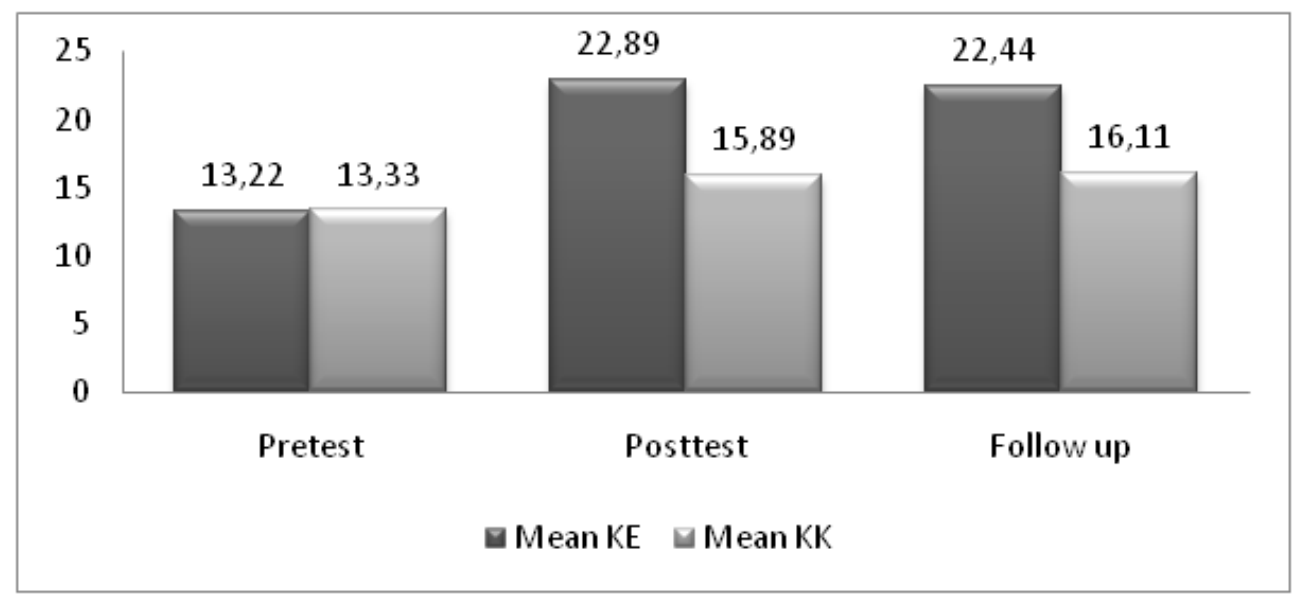

Gambar 2. Grafik Rangkuman Rerata Prates, Pascates, dan Tindak lanjut Pengetahuan Dasar tentang Peserta Didik di Sekolah Inklusi

\section{Hasil Uji Hipotesis}

Analisis uji hipotesis dilakukan dengan tiga cara, yaitu:

1. Hasil uji 2 Independent Samples TTest data selisih skor prates pascates, seperti terlihat pada Tabel 1 , tampak bahwa nilai $\mathrm{p}$ (1-tailed) $=$ $0,0015(p<0,05)$. Dengan demikian, terdapat perbedaan yang signifikan pada pengetahuan dasar guru tentang peserta didik di sekolah inklusi antara kelompok eksperimen dan kelompok kontrol. Pengujian pada data selisih skor tindak lanjut prates tampak bahwa nilai nilai $\mathrm{p}$ (1tailed $)=0,001(p<0,05)$, dengan 
demikian tetap ditemukan adanya perbedaan yang signifikan pada pengetahuan dasar guru tentang peserta didik di sekolah inklusi antara kelompok eksperimen dan kelompok kontrol dalam jangka waktu 6 minggu setelah pemberian psikoedukasi. Hal ini menunjukkan bahwa kelompok eksperimen memiliki pengetahuan dasar guru tentang peserta didik di sekolah inklusi yang lebih tinggi dibandingkan kelompok kontrol dengan rata - rata (pengukuran prates, pascates, dan tindak lanjut) pengetahuan dasar guru tentang peserta didik di sekolah inklusi pada kelompok eksperimen 19,52 dan kelompok kontrol 15, 11.

2. Hasil uji 2 Related Samples T-Test data pascates - prates, seperti terlihat pada Tabel 1, tampak bahwa pada kelompok ekperimen, nilai $p$ (1-tailed) $=0,004(p<0.05)$, artinya ada perbedaan pengetahuan dasar guru tentang peserta didik di sekolah inklusi antara sebelum dan sesudah pemberian psikoedukasi. Hasil uji pada kelompok kontrol, nilai p (1tailed $)=0,0375(p<0,05)$, artinya ada perbedaan pengetahuan dasar guru tentang peserta didik di sekolah inklusi walaupun tidak diberikan psikoedukasi. Hal ini menunjukkan bahwa pengetahuan dasar guru tentang peserta didik di sekolah inklusi antara pascates - prates pada kelompok eksperimen dan kelompok kontrol mengalami peningkatan. Walaupun peningkatan juga terjadi pada kelompok kontrol, namun rerata pascates pengetahuan dasar guru tentang peserta didik di sekolah inklusi kelompok eksperimen lebih tinggi daripada kelompok kontrol (rerata pascates kelompok eksperimen sebesar 22,89 dan rerata pascates kelompok kontrol 15,89).

3. Hasil uji 2 Related Samples T-Test data tindak lanjut - pascates, seperti terlihat pada Tabel 9, tampak bahwa pada kelompok ekperimen, nilai $p(1-$ tailed $)=0,3045(p>0.05)$, artinya tidak ada perbedaan pengetahuan dasar guru tentang peserta didik di sekolah inklusi dalam jangka waktu 4 minggu setelah pemberian pascates pada kelompok eksperimen. Hasil uji pada kelompok kontrol, nilai $\mathrm{p}$ (1tailed $)=0,295(p>0,05)$, artinya tidak ada perbedaan pengetahuan dasar guru tentang peserta didik di sekolah inklusi dalam jangka waktu 4 minggu setelah pemberian pascates pada kelompok kontrol. Hal ini menunjukkan bahwa pengetahuan dasar guru tentang peserta didik di sekolah inklusi antara tindak lanjut pascates pada kelompok eksperimen \& kelompok kontrol tidak mengalami perubahan yang signifikan (rerata tindak lanjut kelompok eksperimen sebesar 22,44 dan rerata pascates kelompok kontrol 16,11). 
Tabel 1. Data Hasil Uji Hipotesis

\begin{tabular}{lc}
\hline \multicolumn{2}{c}{ Uji 2 Independent Samples T-Test } \\
\hline Posttest -Pretest \\
Mann-Whitney U & 7,500 \\
Z & $-2,925$ \\
Asymp. Sig(2-tailed) / (1-tailed) & $0,003 / 0.0015$ \\
Follow up -Pretest & \\
Mann-Whitney U & 5,500 \\
Z & $-3,103$ \\
Asymp. Sig(2-tailed) / (1-tailed) & $0,002 / 0,001$ \\
& \\
\hline$\quad$ Uji 2 Related Samples T-Test & \\
\hline Kelompok Eksperimen & $-2,668$ \\
Posttest -Pretest & $0,008 / 0,004$ \\
Z & \\
Asymp. Sig(2-tailed) / (1-tailed) & $-0,512$ \\
Follow up -Posttest & $0,609 / 0,3045$ \\
Z & \\
Asymp. Sig(2-tailed) / (1-tailed) & \\
Kelompok Kontrol & $-1,782$ \\
Posttest -Pretest & $0,075 / 0,0375$ \\
Z Asymp. Sig(2-tailed) / (1-tailed) & \\
Follow up -Postest & $0,590 / 0,295$ \\
Z & \\
Asymp. Sig (2-tailed) / (1-tailed) & \\
\hline
\end{tabular}

\section{PEMBAHASAN}

Hasil analisis data menunjukkan bahwa hipotesis yang menyatakan bahwa ada pengaruh psikoedukasi "What Every Teacher Should Know About Special Learners" terhadap pengetahuan dasar guru tentang peserta didik di sekolah inklusi dapat diterima dengan catatan adanya peningkatan pada kelompok kontrol. Hal ini menunjukkan bahwa psikoedukasi "What Every Teacher Should Know About Special Learners" berpengaruh terhadap pengetahuan dasar guru SDN “ $X$ " tentang peserta didik di sekolah inklusi (tunagrahita dan kesulitan belajar) dan telah berperan dalam meningkatan 
pengetahuan dasar guru SDN " $X$ ". Peningkatan pengetahuan dasar guru tentang peserta didik di sekolah inklusi juga terjadi pada kelompok kontrol. Walaupun demikian, pengetahuan dasar guru tentang peserta didik di sekolah inklusi pada kelompok eksperimen tetap lebih tinggi dibandingkan kelompok kontrol.

Hasil penelitian ini telah mencapai tujuan penelitian dan membuktikan bahwa psikoedukasi "What Every Teacher Should Know About Special Learners" telah berperan secara optimal dalam upaya meningkatan pengetahuan dasar guru SDN " $X$ " tentang peserta didik (tunagrahita dan kesulitan belajar) di sekolah inklusi. Penelitian ini telah membuktikan bahwa pengembangan profesional dengan psikoedukasi dalam bentuk pelatihan membantu guru mengenali serta menghargai perbedaan kemampaun dan kebutuhan peserta didik (Bennet \& Lopez, 2010). Psikoedukasi "What Every Teacher Should Know About Special Learners" telah mendukung guru SDN " $X$ " dalam mengetahui dan mengenali keberagaman kemampuan dan kebutuhan peserta didik khususnya peserta didik berkebutuhan khusus tunagrahita dan kesulitan belajar. Guru SDN " $X$ " telah memahami materi yang ditunjukkan dengan kemampuan membuat peta pemikiran tentang pengetahuan peserta didik berkebutuhan khusus tunagrahita dan kesulitan belajar.
Guru SDN "X" telah mampu menerapkan pengetahuan untuk mengenali karakteristik peserta didik berkebutuhan khusus tunagrahita dan kesulitan belajar melalui diskusi kasus yang diberikan dalam pelatihan.

Menurut Silberman (1998), Supratiknya (2008), Ormord (2009), serta Parkay dan Stanford (2011), pelatihan yang dikembangkan untuk guru harus dapat meningkatkan pengetahuan dan keterampilan yang sesuai dengan kebutuhan yang mendukung dalam melaksanakan tugas mengajar, memberikan kesempatan untuk belajar aktif, mendemonstrasikan hubungan antar kegiatan pembelajaran, serta menerapkan dalam tugas mengajar. Hasil penelitian ini menunjukkan bahwa pengetahuan dasar guru tentang peserta didik di sekolah inklusi antara kelompok eksperimen lebih tinggi daripada kelompok kontrol.

Beberapa hasil penelitian menunjukkan bahwa psikoedukasi dalam bentuk pelatihan dapat meningkatkan pengetahuan dan kemampuan guru dalam melaksanakan tugas mengajar. Penelitian Noor (2010) mengungkapkan bahwa terdapat perbedaan yang signifikan antara tingkat pengajaran guru sebelum dan sesudah pelatihan. Penelitian Juwono dan Kumara (2011) mengungkapkan bahwa guru menyatakan semakin peka terhadap kebutuhan peserta didik di sekolah inklusi setelah mengikuti pelatihan 
penyusunan rancangan pembelajaran. Hasil penelitian ini menunjukkan bahwa ada perbedaan selisih skor prates dan pascates yang signifikan antara kelompok kontrol dan kelompok eksperimen. Hal ini menunjukkan bahwa psikoedukasi "What Every Teacher Should Know About Special Learners" dapat digunakan sebagai upaya peningkatan pengetahuan dasar guru tentang peserta didik berkebutuhan khusus tunagrahita dan kesulitan belajar. Namun demikian, penelitian yang dilakukan peneliti belum sampai pada melakukan asesmen peserta didik dan merancang program pembelajaran yang mendukung guru mengajar di sekolah inklusi. Oleh karena itu, penelitian ini hanya pada batasan mengantarkan guru SDN " $\mathrm{X}$ " untuk memiliki pengetahuan dan kemampuan dalam menemukenali peserta didik berkebutuhan khusus tunagrahita dan kesulitan belajar sebelum merancang program pembelajaran yang sesuai di sekolah inklusi.

Pada sisi lain, modul psikoedukasi yang digunakan dalam penelitian ini merupakan pengembangan dari manual pelatihan What Every Teachers Should Know About Special Learners dari Tileston (2005) yang belum banyak ditemukan penelitiannya. Selain itu peneliti menyadari bahwa pengembangan modul psikoedukasi dari manual pelatihan tersebut, baru mencantumkan penyusun manual pelatihan dalam kepustakaan, belum ada izin dari penyusun manual pelatihan untuk melakukan pengembangan. Proses perubahan jumlah kegiatan, materi, waktu, lembar kerja dan metode pembelajaran hanya didasarkan pada pemenuhan kebutuhan guru di sekolah inklusi. Pengembangan modul psikoedukasi belum mendapatkan penilaian dari ahli atau guru yang berlatar belakang pendidikan luar biasa. Alat ukur yang digunakan saat pascates dan tindak lanjut masih sama dengan saat prates tanpa ada perubahan yang paralel dengan prates, sehingga ada kemungkinan proses belajar pada kelompok kontrol. Hal ini diduga mengakibatkan adanya kenaikan skor pascates dan tindak lanjut pengetahuan dasar guru tentang peserta didik di sekolah inklusi pada kelompok kontrol. Selain itu, penelitian ini belum melibatkan guru yang mengajar di sekolah inklusi dalam jumlah yang lebih besar. Oleh karena itu, penelitian ini hanya dapat digeneralisasikan pada subjek yang terlibat dalam penelitian ini.

Peneliti melakukan evaluasi psikoedukasi pada akhir pemberian psikoedukasi "What Every Teacher Should Know About Special Learners". Peserta merasakan materi dan tayangan presentasi yang disajikan relevan dengan tugas mengajar dan dapat meningkatkan kesadaran dan pemahaman peserta pelatihan. Pelatih dinilai mampu menyajikan informasi yang mendukung tugas mengajar dengan cara 
memfasilitasi peserta berperan aktif dalam pelatihan, sehingga peserta dapat terlibat aktif menjadi bagian penting dalam keberhasilan kelompok belajar dalam pelatihan.

Selain itu, penyelenggaraan pelatihan dinilai telah sesuai dengan tujuan pelatihan, kegiatan pelatihan terstruktur dan sistematis, serta lingkungan pembelajarannya kondusif. Pendapat peserta yang didapat dari kolom komentar dan saran, pada umumnya menyatakan bahwa pelatihan "What Every Teacher Should Know About Special Learners" sangat penting dan bermanfaat bagi guru dalam mengajar, karena telah membuka dan menambah pengetahuan tentang peserta didik berkebutuhan khusus tunagrahita dan kesulitan belajar. Selain itu, peserta mengharapkan adanya kelanjutan pelatihan asesmen dan merancang program pembelajaran yang sesuai bagi peseta didik berkebutuhan khusus di sekolah inklusi.

Peneliti pada saat tindak lanjut juga melakukan evaluasi setelah 6 minggu mengikuti pelatihan yang menunjukkan bahwa pada umumnya peserta merasa senang karena psikoedukasi "What Every Teacher Should Know About Special Learners" telah menambah wawasan dan pengetahuan tentang tunagrahita dan kesulitan belajar. Peserta semakin memahami peserta didik tunagrahita dan kesulitan belajar, namun belum sepenuhnya menerapkan karena masih perlu waktu dan memerlukan pelatihan lebih lanjut untuk menangani peserta didik berkebutuhan khusus tunagrahita dan kesulitan belajar. Pada akhirnya, pelatihan dalam penelitian ini telah menjadikan subjek penelitian memiliki pengetahuan tentang tunagrahita dan kesulitan belajar yang telah mendukung dalam menangani peserta didik di sekolah inklusi seperti yang dikemukakan Shulman (1986) dan Departemen Pendidikan Nasional (2009)

\section{SIMPULAN DAN SARAN}

\section{Simpulan}

Berdasarkan analisis data dan pembahasan hasil, peneliti menyimpulkan:

1. Ada pengaruh psikoedukasi "What Every Teacher Should Know About Special Learners" terhadap pengetahuan dasar guru tentang peserta didik berkebutuhan khusus di sekolah inklusi, namun dengan catatan adanya peningkatan pada kelompok kontrol. Psikoedukasi "What Every Teacher Should Know About Special Learners" mampu meningkatkan pengetahuan dasar guru SDN " $X$ " tentang peserta didik berkebutuhan khusus tunagrahita dan kesulitan belajar.

2. Ada peningkatan pengetahuan dasar guru tentang peserta didik di sekolah inklusi antara guru SDN " $X$ " dan SDN " $Y$ ". Seluruh guru SDN " $X$ " yang 
diberikan psikoedukasi "What Every Teacher Should Know About Special Learners" mengalami peningkatan pengetahuan dasar. Pengetahuan dasar pada kelompok eksperimen tetap lebih tinggi dibandingkan kelompok kontrol.

3. Seluruh guru SDN " $X$ " mendapatkan manfaat dari psikoedukasi "What Every Teacher Should Know About Special Learners". Guru SDN "X" mendapatkan manfaat berupa bertambahnya pengetahuan dan keterampilan mengetahui serta menemukenali peserta didik tunagrahita dan kesulitan belajar melalui diskusi kasus. Guru SDN " $X$ " semakin mengerti dan memahami pengertian, karakteristik, klasifikasi, dan bagaimana mengidentifikasi peserta didik berkebutuhan khusus tunagrahita dan kesulitan belajar.

\section{Saran}

Berdasarkan pembahasan hasil penelitian, peneliti memberikan saran kepada:

1. Guru dan Sekolah

Bagi guru disarankanan untuk terus menjaga pengetahuan yang telah dimiliki dan terus belajar untuk membuka wawasan mengenai pengetahuan dasar yang diperlukan untuk mengajar peserta didik berkebutuhan khusus di sekolah inklusi. Guru juga disarankan untuk mempraktekan pengetahuan dan kemampuan yang telah didapatkan selama psikoedukasi dalam tugas mengajar di sekolah inklusi. Bagi sekolah, disarankan sekolah untuk dapat memfasilitasi guru dalam memperoleh dan mengembangkan pengetahuan dasar yang dibutuhkan dalam mengajar peserta didik di sekolah inklusi.

2. Pemerintah dan Lembaga Pendidik Tenaga Kependidikan

Bagi pemerintah dan lembaga pendidik tenaga kependidikan diharapkan untuk dapat mengembangkan psikoedukasi bagi guru yang sesuai dengan kebutuhan guru dalam memperoleh dan mengembangkan pengetahuan dasar yang dibutuhkan dalam mengajar peserta didik di sekolah inklusi. Pemerintah dan lembaga pendidik tenaga kependidikan dapat menggunakan dan mengembangkan modul psikoedukasi yang telah disusun peneliti sebagai upaya peningkatan mutu dan kompetensi tenaga pendidik yang mengajar di sekolah inklusi.

3. Praktisi dan Peneliti Selanjutnya

Bagi praktisi psikolog pendidikan dan peneliti selanjutnya apabila melakukan perubahan dalam pengembangan modul psikoedukasi disarankan merujuk pada teori atau penelitian yang sesuai. Penilaian terhadap modul disarankan 
melibatkan ahli yang berlatar belakang pendidikan luar biasa. Praktisi psikolog pendidikan dan peneliti selanjutnya dapat menggunakan dan mengembangkan alat ukur yang telah disusun peneliti dengan melakukan perubahan yang paralel dengan pengukuran pertama pada pengukuran berikutnya serta menggunakan jumlah subjek penelitan lebih banyak dari jumlah subjek yang dilibatkan dalam penelitian yang telah dilakukan peneliti. Praktisi psikolog pendidikan dan peneliti selanjutnya juga dapat melanjutkan tahapan penelitian dengan memberikan materi tentang bagaimana melakukan asesmen dan menyusun program pembelajan serta evaluasinya bagi peserta didik berkebutuhan khusus tunagrahita dan kesulitan belajar di sekolah inklusi. Praktisi psikolog pendidikan dan peneliti selanjutnya juga dapat mengembangkan alat ukur yang telah disusun peneliti untuk kategori peserta didik berkebutuhan khusus yang lain yang ada di sekolah inklusi.

\section{DAFTAR PUSTAKA}

Assessment System Corporation. (1988). MicroCAT (tm) Testing System. Item and Test Analysis Program ITEMAN (tm) Version 3.00. University of Pittsburgh: Assessment System Corporation.
Azwar, S. (2010). Tes Prestasi Fungsi Pengembangan Pengukuran Prestasi Belajar. Yogyakarta: Pustaka Pelajar.

Bennett, S. M. \& Lopez, I. (2010). Culturally Responsive Teaching: A Professional Development Plan for Teachers K-12. Education Thought Leadership Online Journal, 1 - 20. Bloom, B. S., Engelhart, M. D., Furst, E. J., Hill, W. H. \& Krathwohl, D. R. (1956). Taxonomy of Educational Objectives. New York: David McKay Company.

Departemen Pendidikan Nasional. (2009). Pedoman Khusus Penyelenggaraan Pendidikan Inklusi. Pengadaan dan Pembinaan Tenaga Pendidik. Jakarta: Departemen Pendidikan Nasional.

Departemen Pendidikan Nasional. (2009). Peraturan Menteri Pendidikan Nasional Republik Indonesia Nomor 70 Tahun 2009 tentang Pendidikan inklusi bagi peserta didik yang memiliki kelainan dan memiliki potensi kecerdasan dan / atau bakat istimewa. Jakarta: Departemen Pendidikan Nasional.

Field, A. \& Hole, G. (2003). How to Design and Report Experiments. London: Sage Publication Ltd. 
Gibss, G and Coffey, M. (2004). The Impact of Training of University Teachers on Their Teaching Skills, Their Approach to teaching and the Approach to Learning of Their Studnets. Active Learning in Higher Education, 5 (1), 87 - 100.

Juwana, I. D \& Kumara, A. (2011). Pelatihan Penyusunan Rancangan Pembelajaran pada Guru Sekolah Inklusi. Studi Kasus Pada SD " $X$ " di Yogyakarta. Proceeding PESAT (Psikologi, Ekonomi, Sastra, Arsitektur \& Sipil). Universitas Gunadarma - Depok 18 - 19 Oktober 2011. Vol 4 Oktober 2011. ISSN: $1858-2559$

Hadi, S. (2004). Metodologi Research Jilid 1. Yogyakarta: Penerbit Andi Offset.

Hadi, S. (2004). Metodologi Research Jilid 2. Yogyakarta: Penerbit Andi Offset.

Hallahan \& Kauffman. (1994). Exceptional Children Introduction to Special Education (6th ed.). Boston: Allyn \& Bacon.

Hallahan \& Kauffman. (2006). Exceptional Children Introduction to Special Education (10th ed). Boston: Allyn \& Bacon.
Hidayati, K. (2009). Manual Item and Test Analiysis (ITEMAN): Pedoman Penggunaan ITEMAN . http://staff.uny.ac.id/sites/default/fi les/pengabdian/kana-hidayati$\mathrm{m} \mathrm{p} \mathrm{d} \mathrm{/} \mathrm{g} \mathrm{a} \mathrm{m} \mathrm{b} \mathrm{a} \mathrm{r} \mathrm{a} \mathrm{n} \mathrm{-} \mathrm{u} \mathrm{m} \mathrm{u} \mathrm{m} \mathrm{-}$ iteman.pdf.Diakses tanggal 10 November 2012

Krathwohl, D. R. (2002). Revision of Bloom's Taxonomy: An Overview. Theory Into Practice, 41 (4), 212 218.

Mangunsong, F. (2009). Psikologi dan Pendidikan Anak Berkebutuhan Khusus Jilid Kesatu. Depok: LPSP3 UI

Myers, A. and Hansen, C. H. (2002). Experimental Psychology, (5th ed.). Pacific Groves: Wadsworth.

Noor, A. Y. (2010). Program Pelatihan Peningkatan Kemampuan Guru dalam Menerapkan Pengajaran Differentiated Instruction di Kelas Inklusi. Tesis. (Tidak Diterbitkan). Bandung: Konsentrasi Magister Profesi Psikologi Universitas Padjadjaran.

Ormrod, J. E. (2009). Edisi Keenam Psikologi Pendidikan Membantu Siswa Tumbuh dan Berkembang Jilid 1. Terjemahan. Jakarta: Penerbit Erlangga 
Ormrod, J. E. 2009. Edisi Keenam Psikologi Pendidikan Membantu Siswa Tumbuh dan Berkembang Jilid 2. Terjemahan. Jakarta: Penerbit Erlangga

Parkay, F. W. \& Stanford, B. H. (2011). Menjadi Seorang Guru. Jilid 1. Terjemahan. Jakarta: PT. Indeks.

Parkay, F. W. \& Stanford, B. H. (2011). Menjadi Seorang Guru. Jilid 2. Terjemahan. Jakarta: PT. Indeks.

Pellegrino, J. W. (2003). The Challenge of Knowing What Students Know. Measurement: Interdisciplinary Research and Perspectives, 1(1).

Rahman, A. F., Scaife, A., Yahya, N. A., \& Jalil, A. H. (2010). Knowledge of Diverse Learners: Implications for the Practice of Teaching. International Journal of Instruction, 3(2), $83-96$.

Santrock, J.W. (2009). Psikologi Pendidikan Edisi 3 Buku 1. Terjemahan. Jakarta: Penerbit Salemba Humanika

Shadish, W. R. Cook, T. D, and Campbell, D. T. (2002). Experimental and Quasi Experimental Designs for Generalized Causal Inference. Boston: Houghton Mifflin Company.
Shulman, L. S. (1986). Those who understand: Knowledge Growth in Teaching. Educational Researcher, 15(2), $4-31$.

Shulman, L. S. (1987). Knowledge and Teaching: Foundations of the New Reform. Harvard Educational Review, 57(1), 1 - 22.

Silberman, M. (1998). Active Training (2nd ed). San Fransisco, CA: Pfeiffer.

Suparno, Purwanto, H., \& Purwanto, E. (2007). Pendidikan Anak Berkebutuhan Khusus. Jakarta: Departemen Pendidikan Nasional.

Supratiknya, A. (2008). Merancang Program dan Modul Psikoedukasi. Yogyakarta: Penerbit Universitas Sanata Dharma.

Tileston, D.W. (2004). What Every Teacher Should Know About Special Learners. Thousand Oaks, CA: Corwin Press.

Tileston, D.W. (2005). Training Manual for What Every Teacher Should Know. Thousand Oaks, CA: Corwin Press. 